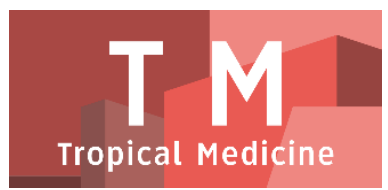

PAPER - OPEN ACCESS

\title{
Low Grade Papillary Urothelial Carcinoma
}

Author : Dedy Suryadi

DOI $\quad: 10.32734 /$ tm.v1i1.54

Paper Page : $119-123$

Volume 1 Issue 1 - 2018 TALENTA Conference Series: Tropical Medicine (TM)

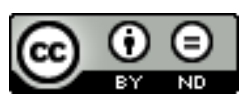

This work is licensed under a Creative Commons Attribution-NoDerivatives 4.0 International License.

Published under licence by TALENTA Publisher, Universitas Sumatera Utara
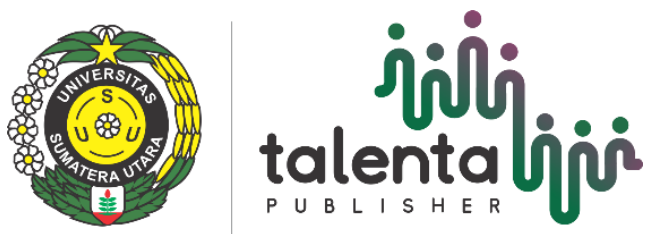


\title{
Low Grade Papillary Urothelial Carcinoma
}

\author{
Dedy Suryadia, Lidya Imelda Laksmi ${ }^{a}$, Jessy Chrestella ${ }^{\mathrm{a}}$ \\ ${ }^{a}$ Departemen Patologi Anatomik, Fakultas Kedokteran, Universitas Sumatera Utara, Medan, Indonesia \\ pedy51yp@yahoo.com
}

\begin{abstract}
Abstrak
Tumor non-invasif merupakan mayoritas neoplasma kandung kemih primer pada diagnosis awal. Sekitar 70-75\% karsinoma urotelial baru adalah non-invasif dan papiler dengan rasio laki-laki-perempuan adalah 3:1. Lebih dari 50\% dari tumor ini adalah low grade. Kami melaporkan kasus perempuan 53 tahun yang mengeluh nyeri pinggang tanpa hematuria. Biopsi jaringan dari kandung kemih dilakukan. Pemeriksaan makroskopik dengan volume $1 \mathrm{cc}$ massa putih keabuan dengan permukaan tidak rata. pemeriksaan mikroskopis tampak jaringan terfragmentasi dengan struktur papiler dan bercabang yang dilapisi oleh lebih dari 7 lapisan epitel transisional dengan inti pleomorfik dan sedikit ireguler, kromatin kasar, beberapa sitoplasma jernih dan aktivitas mitosis rendah. Stroma terdiri dari jaringan ikat fibrosa, dengan pembuluh darah dilatasi dan kongesti. Karcinoma urotelial papiler adalah neoplasma urotelial papiler dengan gangguan cytoarchitectural dalam berbagai tingkatan. Berdasarkan fitur histologis, diagnosis low grade papiler urotelial karsinoma dibuat. Selanjutnya, tumor ini memiliki risiko tinggi mengalami kekambuhan, dan kurang dari 15\% pasien berkembang menjadi penyakit invasif.
\end{abstract}

Kata Kunci: Urothelial Carcinoma; Papillary; Low Grade

\section{Pendahuluan}

Tumor non-invasif merupakan neoplasma kandung kemih paling banyak pada diagnosis awal. Tumor jenis ini dapat dibedakan menjadi 2 kategori, yaitu bentuk papiler dan bentuk flat, yang dapat dijumpai secara terpisah ataupun bersamaan. [5]. Lesi papiler memiliki variasi mulai dari proliferasi reaktif, dan papiloma sampai papillary urothelial neoplasm of low malignant potential, low dan high grade papillary carcinoma. [2].

PUC adalah keganasan yang disebabkan oleh proliferasi urotelial papiler dengan beberapa tingkatan dan gangguan arsitektur yang terlihat pada pembesaran kecil sampai menengah, tanpa invasi ke luar membran basal. [4]. Sekitar 70-75\% dari PUC non-invasif baru. [1]. Rasio laki-perempuan adalah 3:1. Usia penderita rata-rata adalah 70 tahun. [5]. Lebih dari 50\% dari tumor ini low grade. Tumor ini memiliki risiko yang tinggi untuk kambuh kembali, dan $<15 \%$ dari pasien berkembang menjadi penyakit invasif. [8].

Low grade papillary urothelial carcinoma adalah neoplasma urotelial papiler dengan beberapa tingkatan gangguan cytoarchitectural dan perbedaan, dengan kelainan sitologi low grade. [8]. Angka kejadian 5 per 100.000 individu per tahun. [7]. 


\section{Laporan Kasus}

Dilaporkan pasien nyonya S usia 53 tahun dengan keluhan nyeri pada kedua pinggang. Riwayat BAK berdarah disangkal. Dilakukan biopsi jaringan pada pasien ini, kemudian hasil biopsi dikirimkan ke laboratorium patologi anatomi dan diberi label 0/16.07.324. Jaringan yang diterima berupa massa intra vesika urinaria.

Pada pemeriksaan makroskopis diterima jaringan yang berasal dari Intra vesika urinaria. Jaringan tersebut berwana putih keabuan, permukaan tidak rata, konsistensi kenyal dengan volume $1 \mathrm{cc}$.

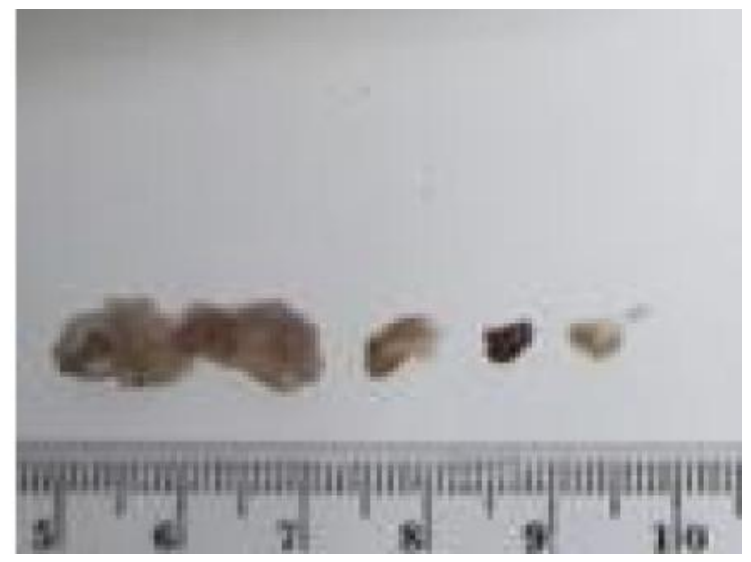

Gambar 1. Jaringan makroskopis yang berasl dari vesika urinaria

Pada pemeriksaan mikroskopis diterima sediaan jaringan dari buli-buli tampak massa tumor yang berfragmentasi berbentuk papil dengan fibrovaskular yang sebagian berfusi memberikan gambaran solid. Struktur papil dilapisi oleh epitel transisional yang lebih dari 7 lapis, inti berbentuk bulat dan oval dengan ukuran bervariasi, kromatin kasar, sebagian hiperkromatik, sitoplasma eosinofilik sebagian jernih. Stroma terdiri dari jaringan ikat fibrous yang diinfiltrasi oleh sel-sel radang limfosit. Pembuluh darah berdilatasi dan kongesti.
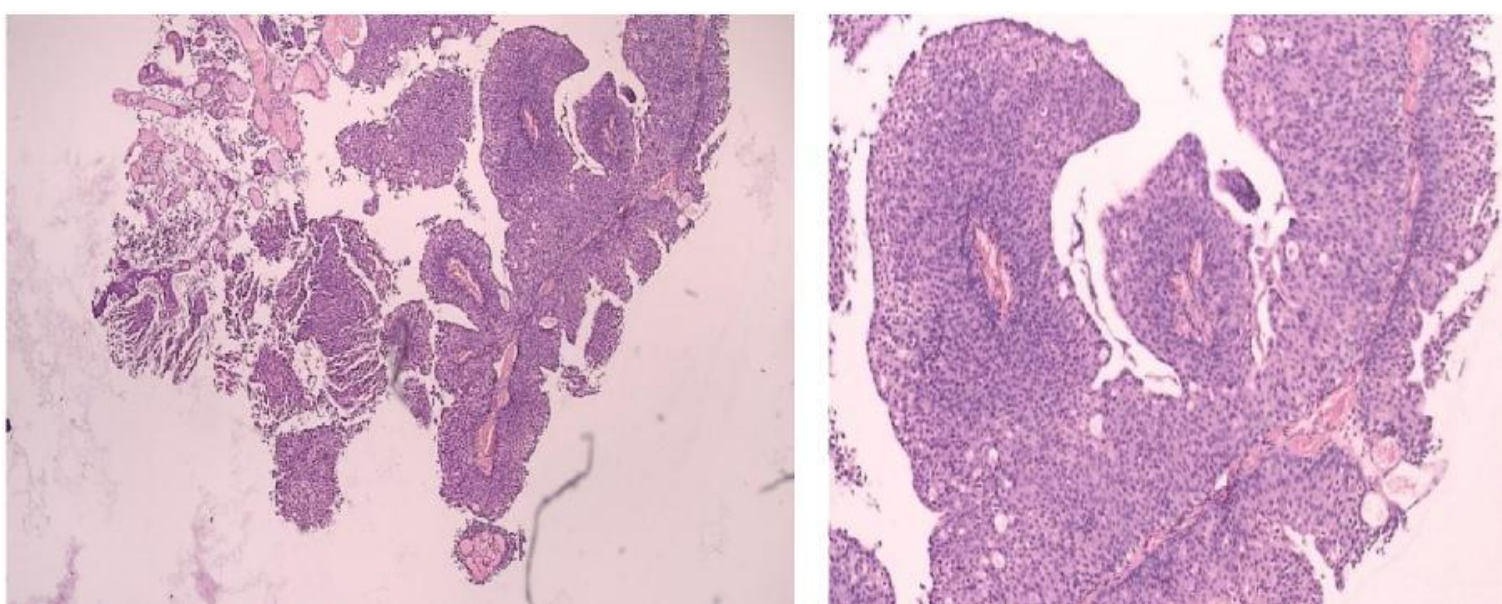

Kesimpulan: Low grade papillary urothelial carcinoma. ICD-O 8130/2

Gambar 2. A. Struktur papiler dengan B Sel-sel transisional yang lebih dari 7 lapisan sel 


\section{Diskusi}

Beberapa faktor dianggap sebagai penyebab terjadinya low grade papillary urothelial carcinoma diantarnya sindrom keganasan yang diturunkan (Lynch syndrome), faktor lingkungan (terpapar bahan kimia), merokok, paparan yang berhubungan dengan pekerjaan (supir terhirup asap kenderaan), arsenic, phenacetin, radiasi radiotheray, infeksi schistosoma. [8].

Gambaran klinis yang paling sering adalah rasa nyeri yang bersifat hilang timbul, buang air kecil disertai darah. Lesi tumor sering soliter dan multipel. [3].

Lokasi yang paling umum adalah pada dinding lateral dan posterior kandung kemih, meskipun demikian neoplasma ini dapat ditemukan di mana saja sepanjang permukaan urothelial. [8]. Pada pemeriksaan cystoscopy, tampak lesi eksofitik, dapat berupa tunggal atau ganda, dan mungkin dengan ukuran yang sangat bervariasi. [4].

Secara histopatologi karsinoma urotelial papiler non-invasif didefinisikan dengan adanya core fibrovascular tipis dilapisi oleh sel urothelium neoplastik dengan ketebalan bervariasi. Heterogenitas pada penggradingan adalah karakteristik dari karsinoma papiler. Saat ini, pendekatan yang berlaku adalah grading tumor berdasarkan komponen grade tertinggi; beberapa penulis menganjurkan 5\% sebagai titik cut-off untuk mengklasifikasikan tumor high grade. Namun, beberapa peneliti telah menemukan bahwa tumor dengan komponen high grade sampai $10 \%$ secara klinis sebagai penyakit ringan. Karena tidak ada konsensus tentang proporsi minimum yang diperlukan untuk membuat diagnosis high grade. Ada beberapa bukti bahwa karsinoma urothelial papiler purely high grade lebih agresif daripada lesi mixed low dan high grade. Hampir semua neoplasma epitel, dalam menentukan grading sangatlah subjektif. Untuk neoplasma urothelial papiler, sistem klasifikasi WHO membutuhkan evaluasi tingkat sitologi dan gangguan arsitektur pada perbesaran rendah dan menengah (100x dan 200x). Gangguan sitologi didefinisikan sebagai kelainan dalam ukuran inti, bentuk, dan kromatin, dan gangguan arsitektur didefinisikan sebagai kelainan orientasi sel dalam hubungan satu sama lain dan ke membran basement papil. [6].

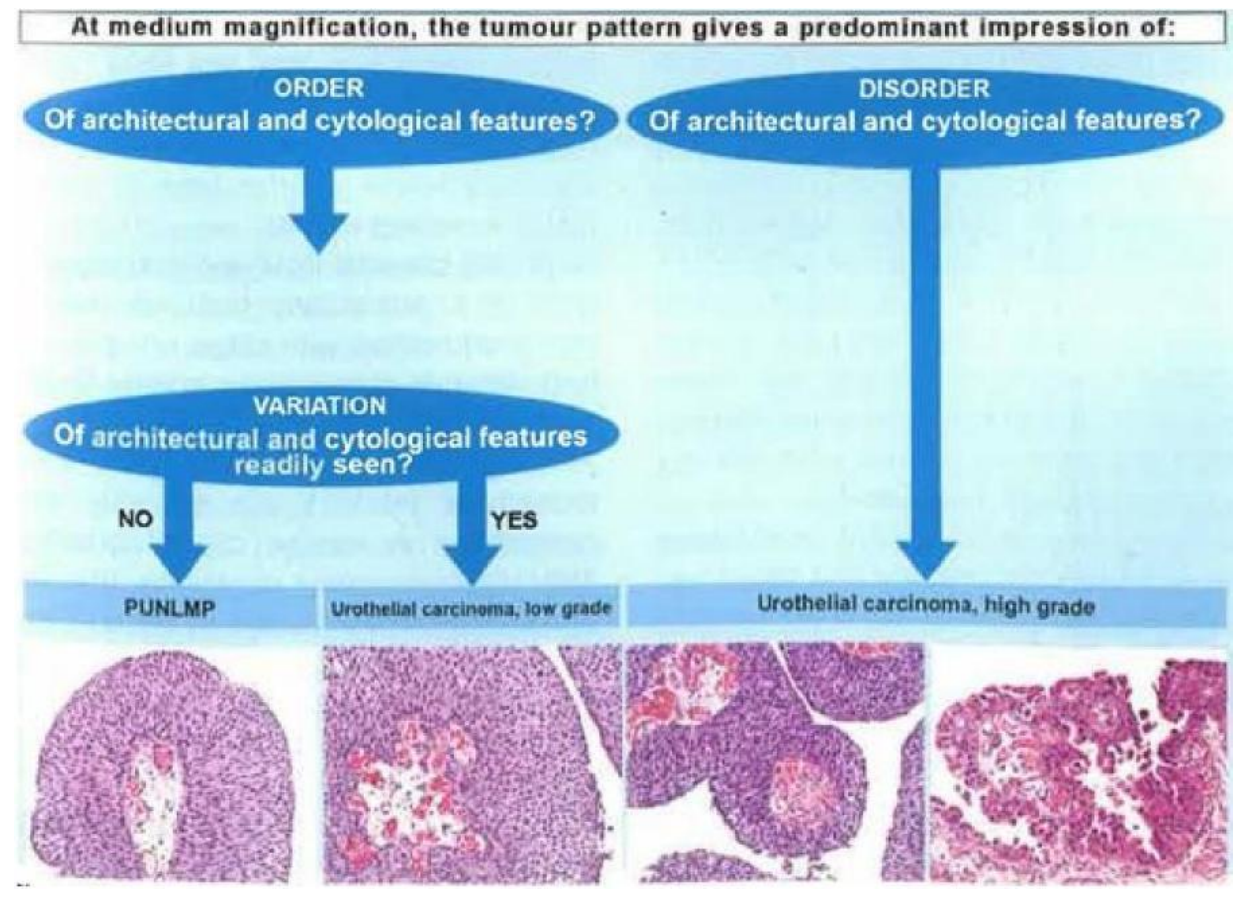

Gambar 3. Algoritma grading papillary urothelial neoplasma

Low grade papillary urothelial carcinoma memiliki papil halus dengan percabangan yang luas. [8]. Pada pembesaran kecil, tampak gambaran yang relatif teratur, tetapi dengan pembesaran sedang, beberapa sel tumor 
kehilangan polaritas serta ketidakteraturan inti ringan dan pleomorfisme yang jelas. [4]. Mitosis mungkin atau mungkin tidak dijumpai, tapi biasanya non-atipikal dan dapat ditemukan jauh dari membran basal. [7].

Profil genetik saat ini menunjukkan bahwa karsinogenesis urothelial terjadi sebagai efek yang melibatkan sejumlah lokasi di mukosa kandung kemih. Semakin banyak bukti mendukung gagasan bahwa sel induk urothelial di daerah yang terkena diubah menjadi sel-sel induk kanker dengan mengakuisisi perubahan genetik yang menyebabkan pembentukan tumor melalui ekspansi klonal. tumor kandung kemih timbul melalui setidaknya dua mekanisme terpisah yaitu jalur FGFR3 dan jalur TP53. Tumor berasal dari dua jalur ini muncul sebagai kelompok heterogen dengan fenotip dan genotip yang berbeda, dan dengan perilaku biologis dan hasil klinis yang sangat berbeda. Low-grade tumor non-invasif ditandai dengan mengaktifkan mutasi FGFR3, namun high grade karsinoma urothelial ditandai dengan perubahan genetik atau epigenetik pada gen TP53 atau dalam gen regulasi TP53, seperti CDKN2A. Mutasi FGFR3 biasanya terjadi padakarsinoma papiler low grade oleh karena ketidakstabilan genetik yang terbatas, sedangkan karsinoma urothelial high grade ditandai dengan mutasi TP5. Mutasi FGFR3 juga telah dilaporkan pada lesi yang diklasifikasikan sebagai urothelial dan inverted papiloma. [8]

Prognosis tergantung pada faktor klinis dan morfologi. Faktor prognostik penting untuk urothelial karsinoma non-invasif menurut WHO / International Society of Urological Patologi (ISUP) termasuk grade histologis, yang merupakan salah satu faktor prognostik dan prediktif yang paling penting. Rekurensi dan peningkatan stage, masingmasing adalah 36\% dan $4 \%$ untuk neoplasma papiler urothelial potensi low malignant dan 50\% dan $10 \%$ untuk karsinoma low grade. Pada karsinoma high grade, tingkat kekambuhan 60\%, dan tingkat pengembangan untuk lamina propria dan invasi muskularis propria adalah masing-masing 25\% dan 5\%. [8]

Meskipun tidak ada penanda imunohistokimia prognostik yang saat ini direkomendasikan dalam praktek rutin, ada beberapa bukti bahwa peningkatan tingkat proliferasi yang ditentukan oleh Ki-67 ekspresi, sendiri atau dikombinasikan dengan p53, dapat memprediksi risiko kekambuhan dan perkembangan penyakit. Pewarnaan CK20 telah dilaporkan berhubungan dengan kekambuhan. Profil normal CK20 (Pewarnaan lokal ke lapisan sel payung) telah ditunjukkan dapat memprediksi risiko kekambuhan yang lebih rendah. [4].

Mutasi pada FGFR3 sering dijumpai pada karsinoma urotelial papiler low grade noninvasif dan berkaitan dengan risiko rendah terjadinya kekambuhan, tapi tergantung juga pada hilangnya alel di 9p22. Delesi PTEN berhubungan dengan peningkatan kekambuhan pada pTa kanker kandung kemih. Studi FISH yang mendeteksi perubahan kromosom pada urine juga mampu memprediksi kekambuhan penyakit setelah reseksi tumor pada pasien dengan temuan sitologi yang normal. [7].

Peningkatan staging relatif jarang pada neoplasia urotelial low grade, data tentang pentingnya prognostik dengan adanya perubahan genetik pada tumor ini masih sangat kurang. Perubahan molekuler menunjukkan hubungan peningkatan risiko dengan perkembangan kanker kandung kemih pTa termasuk akumulasi p53, inti kehilangan ekspresi p63, membran kehilangan ekspresi E-cadherin, dan delesi RB. Selain itu, LOH di 16p13 dan perubahan kromosom yang melibatkan 3p, 4p, Sp, 5q, 6q, 10q, dan 18q juga menjadi prediktor terhadap peningkatan risiko pengembangan penyakit invasif. [8].

\section{Kesimpulan}

Papillary Urothelial Carcinoma adalah keganasan yang disebabkan oleh proliferasi urotelial papiler dengan beberapa tingkatan dan gangguan arsitektur yang terlihat pada pembesaran kecil sampai menengah, tanpa invasi ke luar membran basal. Berdasarkan gambaran histologis, kasus ini didiagnosis karsinoma urotelial papiler low grade. Selanjutnya, tumor ini memiliki risiko tinggi terjadi kekambuhan dan kurang dari $15 \%$ pasien berkembang menjadi penyakit invasif.

\section{Daftar Pustaka}

[1] Alpers CE, Anthony DC, Crawford JM, Girolami UD, Ellenson LH, Epstein JI. (2010). The Lower Urinary Tract. . In: Kumar V, Abbas AK, Fausto N, Aster JC, editors. Robbins and Cotran pathologic basic of disease. 8th edition. Philadelphia: Saunders; 2010 , Chapter 21. 
[2] Antonio Lopez-Beltran, Rodolfo Montironi, Alfredo Vidal-Jimenez, and Liang Cheng. (2007). Non-invasive papillary urothelial carcinoma, low- and high-grade, Pathology of tumors of the urinary bladder. In: Gregor Mikuz, editors. Clinical Pathology of Urologic Tumors. London: Informa Healyhcare; 2007. 63.

[3] Jung-Weon Shim, Kang Su Cho, Young-Deuk Choi, Yong-Wook Park, Dong-Wha Lee, Woon-Sup Han. (2008). Diagnostic algorithm for papillary urothelial tumors in the urinary bladder. Received: 28 September 2007 / Revised: 19 December 2007 / Accepted: 19 January 2008 / Published online: 1 March 2008 \# Springer-Verlag 2008.

[4] Khan JKC, Arber DA, Brunning RD, Desmet VJ, Kleinschmidt-Demasters BK, Ordonez NG. (2011). Urothelial (transitional cell) carcinoma. In: Rosai J, editors. Rosai and Ackermanes surgical pathology. 10th edition. Volume 1. Missouri: Mosby Elsevier; $2011.1257-$ 65.

[5] Ming Zhou, George Netto, Jonathan Epstein. (2012). Low-Grade Papillary Urothelial Carcinoma. In: Ming Zhou, George Netto, Jonathan Epstein, editors. Uropathology: High-Yield Pathology. Philadelphia: Saunders; 2012. 182.

[6] Miyamoto Hiroshi, Fadi Brimo, Luciana Schultz, Huihui Ye, Jeremy S. Miller, Daniel A. Fajardo. (2010). Low-Grade Papillary Urothelial Carcinoma of the Urinary Bladder A Clinicopathologic Analysis of a Post-World Health Organization / International Society of Urological Pathology Classification Cohort From a Single Academic Center. Arch Pathol Lab Med. 2010;134:1160- 1163.

[7] Parakh R. (2016). Urothelial neoplasms-noninvasive Low grade papillary urothelial carcinoma [Internet]. USA: PathologyOutlines.com; 2014 [updated 2016 July 12; cited 2016 August 14]. Available from: http://www.pathologyoutlines.com/topic/bladderLGpap.html

[8] Reuter VE, Algaba F, Amin MB, Cao D, Cheng L, Comperal E. (2016). Non-invasive urothelial lesions. In: Holger Moch, Peter A. Humphrey, Thomas M. Ulbright, Victor E. Reuter, editors. WHO Classification of Tumours of the Urinary System and Male Genital Organs. Lyon: IARC Press; 2016. 99-102. 